\title{
Mapping of available nutrients in soils of Ambala district (Haryana)- A GIS approach
}

GURU PREM, ANURAG KUMAR, RAKESH CHOUDHARY, VIKRAM D. SINGH, RAMESH KUMAR AND AMIT KUMAR

Received : 16.03.2017; Revised : 18.04.2017; Accepted : 01.05.2017

MEMBERS OF RESEARCH FORUM:

Corresponding author : GURU PREM, Krishi Vigyan Kendra, AMBALA (HARYANA) INDIA Email: gpgrover79@gmail.com

Co-authors :

ANURAG KUMAR, Department of Agro-meteorology, C.C.S. Haryana Agricultural University, HISAR (HARYANA) INDIA

Email: anurag.airon@gmail.com

RAKESH CHOUDHARY, VIKRAM D. SINGH, RAMESH KUMAR AND AMIT KUMAR, Krishi Vigyan Kendra, AMBALA (HARYANA) INDIA

Email: rakeshnitharwa19@gmail.com; vdskvkambala@gmail.com; rjhorar73@gmail.com; amitbaliyan2009@gmail.com

\section{Summary}

The current study was carried out to assess the GIS map-based soil fertility evaluation with regard to traditional soil testing in the Ambala. This study presents the soil spatial variability maps for soil $\mathrm{pH}$, electrical conductivity, organic carbon, available $\mathrm{N}, \mathrm{P}, \mathrm{K}, \mathrm{S}, \mathrm{Zn}, \mathrm{B}, \mathrm{Fe}, \mathrm{Mn}$ and $\mathrm{Cu}$. Soil samples were collected during Rabi season of year 2015. Nearly 70 per cent samples had $\mathrm{pH}$ between 6.8 and 8.2. The electrical conductivity (EC) varied from 0.10 to 0.98 $\mathrm{dS} \mathrm{m}{ }^{-1}$ with an average value of $0.39 \mathrm{dS} \mathrm{m}^{-1}$. The organic carbon $(\mathrm{OC})$ in these soils ranged between 0.2 and 0.59 per cent with an average value of 0.37 per cent, the distribution of OC was 58, 42 and 0 per cent, respectively as low, medium and high rating. All the soil samples tested were found to be deficient in N. Only 18 per cent soil samples were deficient in available P, while 62 and 20 per cent samples had medium to high P status. Eighteen (18) per cent samples were found to be low, whereas 74 per cent samples were medium and remaining 10 per cent samples tested high in available K status. 28 per cent samples fell under low status and 40 per cent samples were medium and 32 per cent samples were in high S status. Majority of the soil (96\%) samples were having low status of B. 14.00 per cent samples fell under medium status, 6.00 per cent samples were normal and 80.00 per cent samples were high in $\mathrm{Zn}$ status. All the soils had sufficient amount of $\mathrm{Fe}$ and $\mathrm{Cu}$.

Key words : Soil testing, Macro, Micro-nutrients, GIS maps

How to cite this article : Prem, Guru, Kumar, Anurag, Choudhary, Rakesh, Singh,Vikram D., Kumar, Ramesh, and Kumar, Amit (2017). Mapping of available nutrients in soils of Ambala district (Haryana)A GIS approach. Asian J. Soil Sci., 12 (1) : 86-93 : DOI : 10.15740/HAS/AJSS/12.1/86-93. 